\title{
Nauczyciel według św. Augustyna
}

\section{The Teacher According to St. Augustine}

\begin{abstract}
ABSTRAKT
Celem artykułu jest przedstawienie koncepcji nauczyciela według św. Augustyna, jednego z Ojców Kościoła, opartej na analizie wybranych dzieł z jego spuścizny literackiej. Niniejsze opracowanie jest ograniczone do najważniejszych pozycji literaturowych dotyczqcych poruszanego tematu. Artykuł definiuje pojęcie nauczania, zgodnie z poglaqdami Augustyna, a następnie przedstawia jego doświadczenia w zakresie edukacji w wieku dziecięcym i młodzieńczym, zestawiajqc z nimi późniejsze stwierdzenia tego wybitnego retora na temat procesu nauczania. Prezentuje obraz Augustyna jako nauczyciela, wynikajqcy z analizy jego dzieł i wspomnień, zwracając uwagę na te jego cechy i umiejętności, które sq szczególnie istotne w procesie edukacyjnym. Szczegółowo przywołane również zostały wskazania, jakich biskup z Hippony udzielał tym, którzy pragnęli wykładać wiedzę innym oraz możliwe trudności, z jakimi mogq się oni spotkać. W zakończeniu wskazano filary, na których zasadza się Augustyńska koncepcja nauczania. Artykuł jest próbq zwrócenia uwagi na podstawowe wymogi wobec nauczyciela oraz zawiera wskazówki, które mogq być przez niego wykorzystane w praktyce, aby doskonalić swoje umiejętności w przekazywaniu wiedzy drugiemu człowiekowi.
\end{abstract}

SLOWA KLUCZOWE edukacja, nauczyciel, uczeń, Augustyn, mq̨drość

\section{KEYWORDS}

education, teacher, student, Augustine, wisdom

SPI Vol. 24, 2021/3

ISSN 2450-5358

e-ISSN 2450-5366

DOI: 10.12775/SPI.2021.3.002

Nadestano: 23.06.2021

Zaakceptowano: 17.09.2021

Artykuły i rozprawy 


\section{ABSTRACT}

The subject of the article is the concept of a teacher according to St. Augustine, one of the Fathers of the Church, based on the analysis of selected works from his literary legacy. This study is limited to the most important literature on the topic. The article defines the concept of teaching, in line with the Augustine's views, and then presents his experiences of education in childhood and adolescence, juxtaposing later statements by this eminent rhetorician about the teaching process. It presents the image of Augustine as a teacher, resulting from the analysis of his works and memorials, pointing to his qualities and skills that are particularly important in the educational process. The indications that the Bishop of Hippo gave to those who wished to teach others to learn and the possible difficulties they might encounter were also cited in detail. At the end, the pillars on which the Augustinian teaching concept is based are indicated. The article shows the basic requirements for a teacher and tips that can be used by them in practice to improve their skills when teaching other people.

\section{Wprowadzenie}

Przybliżając stanowisko Augustyna, dotyczące właściwej postawy i działań nauczyciela, należy podkreślić, że wpływ na jego postrzeganie procesu nauczania miały dzieciństwo i młodość, w czasie których doświadczał często wielu rozczarowań związanych ze swoją edukacją. Przechował je jednak w pamięci i jako „rzeczy cenne” wykorzystał do tego, aby w przyszłości pokazać, jak należy pojmować cel nauczania i unikać w ten sposób wywierania zgubnego wpływu na młodego człowieka (Augustyn 2007: I, 7).

Nauczanie stanowiło w życiu biskupa z Hippony jedną z najważniejszych kwestii, gdyż pełniąc coraz wyższe funkcje w Kościele, właśnie poprzez proces edukacji swych słuchaczy dzielił się z nimi swą wiedzą i przemyśleniami. Jego podstawowym celem było zawsze przybliżenie otaczających go ludzi do Chrystusa. Aby wypełnić tak szczytne zadanie, Augustyn najpierw próbował zrozumieć sposób zachodzenia procesów poznawczych, następnie rozważał ograniczenia towarzyszące próbom przekazania wiedzy, a ostatecznie wskazywał podstawowe warunki sine qua non dla prawidłowej realizacji tego procesu. Przede wszystkim jednak nie tylko mówił o tym, jak uczyć, 
ale własnym sposobem głoszenia i nieustannie podejmowanymi próbami życia zgodnie $\mathrm{z}$ tym, czego nauczał, dawał innym najlepszy przykład. W tym kluczu - świadectwa życia, a następnie wskazówek, jakie zostawił Augustyn, niniejszy artykuł przedstawia filary, na których swoje metody edukacyjne powinien oprzeć każdy nauczyciel.

Za tym, że nauczanie w życiu Augustyna stanowiło kwestię priorytetową, przemawia również fakt, że walczył $z$ herezjami swoich czasów poprzez publiczne dysputy, pisanie listów do oponentów, wyjaśnianie prawd wiary ${ }^{1}$, a także troska, jaką okazywał w stosunku do biblioteki kościelnej oraz przechowywanych w niej pism: „Nie sporządził żadnego testamentu, ponieważ jako biedak Boży nie miał nic, z czego mógłby to zrobić. Zawsze nakazywał, ażeby biblioteka kościelna i wszystkie kodeksy starannie były strzeżone dla potomnych" (Possydiusz z Kalamy 2002: XXI, 6).

Wspomniane elementy do dziś są przedmiotem wielu analiz i opracowań, co jest możliwe jedynie dzięki temu, że dzieła Augustyna zachowały się niemal w całości. Jego nauczanie wywarło wielki wpływ na ukształtowanie dogmatów Kościoła, ale również na filozofię, pedagogikę i inne dziedziny istotne dla ludzkiej działalności. Poddając analizie jego najważniejsze dzieło $\mathrm{z}$ zakresu nauczania O Nauczycielu, zdefiniowane zostaną podstawowe pojęcia przybliżające sposób podejścia do tych kwestii przez Augustyna.

\section{Definicje podstawowych poięć}

W dialogu filozoficznym O Nauczycielu Augustyn rozróżnia takie pojęcia jak: znaki, nazwy, słowa, mowa oraz nauczanie, które zostaną pokrótce zdefiniowane w niniejszym artykule.

Znak, nazwa i słowo są pojęciami używanymi przez Augustyna zamiennie. $\mathrm{Za}$ ich pomoca filozof ukazuje jednak proces poznania, jaki zachodzi u osoby zdobywającej wiedzę: „Skoro bowiem dają mi znak, to gdy nie wiem, w danej chwili, jakiej rzeczy to znak, wówczas nie może mnie on niczego nauczyć; jeśli zaś wiem, co to za rzecz,

1 Zob. Possydiusz z Kalamy (2002: XVIII, 9): „Tak wiele dyktował i wydawał, tak wiele $\mathrm{z}$ tego, co głosił w kościele, zostało spisane i wydane, czy to pism przeciwko różnym heretykom, czy też wykładów z ksiąg kanonicznych [pisanych] dla zbudowania synów Kościoła, że każdy, kto się nimi zajmuje, ledwie może je wszystkie przeczytać i się z nimi zapoznać”. 
to co mi ten znak może więcej o niej powiedzieć? (...) Gdy po raz pierwszy te dwie zgłoski, które wymawiamy mówiąc «głowa», dotarły do moich uszu, tak samo nie wiedziałem, co one oznaczają, jak wtedy, kiedy po raz pierwszy usłyszałem lub przeczytałem wyraz «saraballe»; ale ponieważ często powtarzano słowo «głowa», zwracałem pilnie uwagę, kiedy je wymawiają i przekonałem się, że jest to wyraz oznaczający rzecz znaną mi doskonale $\mathrm{z}$ widzenia. Zanim jednak stwierdziłem to, słowo to było dla mnie tylko pustym dźwiękiem. (...) Tak więc raczej znajomość rzeczy prowadzi do poznania znaku niż znak do poznania wiedzy" (Augustyn 1999a: X-33). Za jedyną wartość słów Augustyn uznaje pobudzanie ludzi do szukania wiedzy. Nie potrafią one bowiem same tak pokazać człowiekowi nauczanych treści, aby on je rzeczywiście poznał. Proces ten jest odwrotny - to poznanie rzeczy prowadzi do poznania słów.

Mowa według Augustyna jest również znakiem, ponieważ nie ma możliwości przekazania drugiej osobie wiedzy bez użycia znaków. Podstawowym jednak jej celem nie jest samo ich stosowanie, ale nauczanie.

Sposób rozumienia przez Augustyna terminu „nauczanie” najlepiej widoczny jest w stwierdzeniu: „Słowa istnieją przecież po to, aby ich używać; używamy ich zaś do nauczania. I o ile doskonalszą jest rzeczą nauczać, niż tylko mówić, o tyle doskonalsza jest mowa od słów. A już nauka od słów jest o całe niebo więcej warta” (Augustyn 1999a: IX-26). Średniowieczny filozof uważa, że pouczać innych można również stosując inne znaki niż sama mowa. Wynika $z$ tego, że nauczanie jest znacznie szerszym pojęciem od posługiwania się słowami. Na podstawie przytoczonego cytatu można jednak wysnuć wniosek, że według Augustyna nauczycielem jest każdy, kto używa słów - niezależnie od tego, czy następuje to poprzez pouczanie drugiego, czy poprzez przypominanie mu pewnych kwestii, które są już dla niego znane (Augustyn 1999a: I-1).

\section{Doświadczenia dzieciństwa i młodości}

Swoje spostrzeżenia dotyczące własnej edukacji Augustyn opisał w Wyznaniach. Pierwsze jego doświadczenia dotyczyły nauki mowy. Podkreślał, że przychodziła mu ona z łatwością, przede wszystkim ze względu na fakt, że „swobodne zainteresowanie bardziej sprzyja 
uczeniu się języka niż jakakolwiek przymusem narzucona pilność” (Augustyn 2007: I, 14). Etap tej nauki domowej, podczas której małe dzieci uczą się mówić, upłynął dość szybko i Augustyn został posłany do szkoły w wieku dziecięcym, gdzie bardziej cenił sobie zabawę niż zdobywanie wiedzy. Wobec jego niechęci do nauki nauczyciele często stosowali przemoc w formie batów (Augustyn 2007: I, 9). Młodemu Augustynowi nie brakowało zdolności czy pamięci, ale jego umysł lgnął bardziej do przyjemności. $Z$ tego też względu, pomimo cierpienia, jakiego przysparzały mu stosowane przez nauczycieli metody, przyznał po wielu latach: „Przymuszano mnie i na dobre mi to wyszło, chociaż sam nie postępowałem dobrze: nie uczyłbym się bowiem, gdyby mnie nie zmuszono" (Augustyn 2007: I, 12). Problemy na pierwszym etapie edukacji dotyczyły głównie nauki czytania, pisania, podstaw matematyki oraz greki. Budziły one w młodym Augustynie tym większy opór, im bardziej go do niej zmuszano, głównie z powodu konieczności powtarzania czy czytania wielu rzeczy bez ich zrozumienia (Augustyn 2007: I, 13-14). Dużą rolę w tym procesie odegrała również postawa nauczycieli, nie tylko stosowane kary, ale przede wszystkim ich zachowanie: „Przepadałem jednak za zabawami. Karę zaś wymierzali mi ludzie, którzy też się zabawiali. (...) Czyż człowiek, który mnie bił, zachowywał się w życiu lepiej ode mnie? Jeśli w jakiejkolwiek dyspucie został przez innego uczonego pokonany, bardziej go żółć zalewała niż mnie, gdy przegrałem z kolegą w piłkę" (Augustyn 2007: I, 9). Nie stanowili oni autorytetu dla Augustyna, co negatywnie wpływało na jego postawę wobec konieczności nauki.

W dzieciństwie jako wzór do naśladowania stawiano mu ludzi „którzy wstydzili się jak hańby tego, że opowiadając o dobrych swoich czynach, popełnili błąd gramatyczny albo użyli wyrażeń prowincjonalnych, a dumnie kroczyli w obłoku pochwał, jeśli o swoich niegodziwych pasjach mówili zdaniami zaokrąglonymi, błyszczącymi obfitą ornamentyką" (Augustyn 2007: I, 18). Wspominając te chwile, Augustyn wskazuje na błędne pojmowanie celu samej nauki, ponieważ ludzie ci bardziej zwracali uwagę na formę niż na treść, a także większą wagę przykładali do poprawnego sposobu mówienia niż do przykładnego życia (Augustyn 2007: I, 18). Sam zaś Augustyn w dialogu z rozumem przyzna, że podziw i zaszczyty tego świata nie są nic warte w porównaniu z poznaniem prawdziwej mądrości: „Ja jedynie mądrość kocham dla niej samej - wszystko inne: życie, spokój, przyjaciól, cenię 
tylko ze względu na nią" (Augustyn 1999c: XIII-22). Żadne słowa, choćby wypowiedziane w najlepszym stylu, przy użyciu pięknej składni, nie nadadzą fałszywemu zdaniu prawdziwości, ani mądrości temu, co jest od niej dalekie (Augustyn 2007: V, 6). Augustyn natomiast doceniając zmienną mądrość ludzką, którą nabywa się w czasie, wskazuje jednocześnie na źródło prawdziwej, niezmiennej Mądrości, którą jest sam Bóg i stwierdza: „Kto tego nie rozumie, podobny jest do ślepca patrzącego w słońce, któremu na nic zda się blask zalewający jego oczodoły. Ten zaś, kto widzi, lecz odwraca się od tego, co widzi, temu przyzwyczajenie do cielesnych ciemności przytępiło bystrość umysłu. Tacy ludzie są niejako odpychani od ojczyzny przez przeciwne wiatry wywołane przez ich złe obyczaje. Szukają oni dóbr niższych pod względem znaczenia i wartości w stosunku do takich, jakie sami uważają za lepsze i szacowniejsze" (Augustyn 1989: IX 9). Zatem koncentrowanie się na tym, co jest przyziemne, $\mathrm{w}$ tym również na formie wypowiedzi czy pragnieniu zdobycia poklasku, odrywa ludzi od dążenia do osiągnięcia prawdziwej mądrości.

Rolę nauczyciela wobec tych, którzy rzeczywiście dążą do poznania prawdziwej mądrości, Augustyn przedstawia posługując się platońską teorią iluminacji: „Mądrość jest jakąś nie dającą się wyrazić ani pojąć światłością umysłu" (Augustyn 1993c: XIII-23). Każdy człowiek dochodzi do jej poznania w nieco inny sposób - niektórzy moga patrzeć od razu prosto w słońce tej światłości, inni jednak potrzebują dłuższej drogi, ponieważ porażeni blaskiem z radością powracają $\mathrm{w}$ mrok niewiedzy. Rolą nauczyciela jest rozpoznać, $\mathrm{z}$ jaką osobą ma do czynienia i odpowiednio nią pokierować. Potrzebujących wolniejszego procesu należy prowadzić drogą od pobudzania tęsknoty za światłem, poprzez pokazywanie czegoś, co jeszcze nim nie jest, ale odbija światło mądrości w coraz większym stopniu, aż do poznania prawdziwego jej światła: „W ten sposób człowiek taki, wcześniej czy później, przeszedłszy wszystkie stopnie po kolei, albo niektóre z nich pominąwszy, będzie się powoli przyzwyczajał do jasności stosownie do stanu zdrowia swoich oczu, aż wreszcie spojrzy na słońce bez obawy i z wielką rozkoszą" (Augustyn 1999c:XIII-23).

Ogromną rolę w osiąganiu zamierzonego celu odgrywa, według Augustyna, także wewnętrzna motywacja. Już w dzieciństwie z duża łatwością - bez konieczności stosowania kar - w naturalny sposób nauczył się łaciny, "gdyż własne serce mnie przynaglało, bym 
jak najszybciej zaczął wyrażać jego pragnienia” (Augustyn 2007: I, 14). Jako student Augustyn uczestniczył w zajęciach, ale - jak sam przyznaje - głównym źródłem jego wiedzy była samodzielna nauka. Jego bystry umysł nie potrzebował bowiem oświecenia od nauczycieli, gdyż nawet bardzo trudne kwestie z zakresu retoryki, geometrii, muzyki czy matematyki opanował, czytając o nich w książkach. O tym, że zagadnienia te mogą być trudne do zrozumienia, przekonał się dopiero będąc nauczycielem i próbując przekazać swą wiedzę innym: „Tylko najwybitniejsi z moich uczniów potrafili nadążać za tokiem mojego wykładu" (Augustyn 2007: IV, 16). Mimo wszystko, jako nauczyciel retoryki, starał się rzetelnie wykładać innym tę naukę, którą sam potem określił jako „sztukę, która miała im umożliwić panowanie nad przeciwnikami w dyskusjach" (Augustyn 2007: IV, 2).

Doświadczenia,jakie zdobył Augustyn w dzieciństwie i młodości, ukształtowały go jako przyszłego nauczyciela. Potrafił się wykazać zrozumieniem istoty nauczania, roli motywacji wewnętrznej ucznia, a także odpowiednią postawą osoby, która przekazuje wiedzę innym.

\section{Augustyn jako nauczyciel}

Augustyn nauczając, prowadząc dysputy $z$ heretykami, rozmowy z braćmi, z którymi mieszkał, a nawet z samym sobą, najczęściej wybierał formę dialogu. Stanowi to przejaw wpływu, jaki na sposób myślenia Augustyna wywarła filozofia neoplatońska (Trapè 1987: 94-95). Dialog umożliwiał mu zastosowanie specyficznej metody nauczania. Augustyn kładł nacisk przede wszystkim na zrozumienie przez ucznia wykładanej treści. Jego metodę pedagogiczną w praktyce znakomicie uwidacznia dzieło O Nauczycielu, w którym rozmawia ze swoim synem, Adeodatem, na temat celu i sposobu używania słów. Cierpliwie omawiają każdą kwestię, a w przypadku, gdy uczeń czegoś nie rozumie, Augustyn nie kontynuuje tematu, ale powraca do zagadnień uprzednio zrozumianych. Następnie inną drogą, poprzez lepiej dobrane przykłady, prowadzi Adeodata do zrozumienia tego, co chciał mu przekazać. $Z$ jednej strony dostosowuje się więc do tempa i sposobu myślenia ucznia, a jednocześnie nie zwalnia go z konieczności samodzielnej pracy umysłowej: „Adeodat: Teraz więc objaśnij mi, w jaki sposób dałem się zwieść temu rozumowaniu, z którego wynika, że nie jestem człowiekiem? Augustyn: Raczej zadam ci te 
same pytania jeszcze raz żebyś sam stwierdzi1, gdzieś się potkną” (Augustyn 1999a: VIII-22).

Augustyn stosował niezwykle biegle metodę prostych porównań, które umożliwiały uczniowi zrozumienie trudnych tematów: „Mówić bowiem słowami o słowach jest rzeczą tak skomplikowaną, jak spleść palce obu dłoni, a następnie pocierać je o siebie. Kto wtedy lepiej niż ten, co to robi, może odróżnić, które palce doznają swędzenia, a które je uśmierzają? Adeodat: Słucham z całym skupieniem, bo porównanie to wprawia mnie w najwyższe zaciekawienie" (Augustyn 1999a: V-14). Podobnie postępował w czasie, gdy pełnił posługę kaznodziei i biskupa. W jego kazaniach oraz objaśnieniach do Psalmów można znaleźć wiele przykładów z życia codziennego, które umożliwiały słuchaczom nie tylko zrozumienie wykładanych przez niego treści, ale również zapamiętanie ich i zastosowanie wysłuchanych nauk w praktyce (Trapè 1987: 146). Augustyn nie zrezygnował również zupełnie $\mathrm{z}$ formy dialogu, ale - ponieważ w głoszeniu homilii nie była ona możliwa - dostosował ją do panujących warunków, zadając w swoich mowach wiele pytań, które pozwalały słuchaczowi skonfrontować się z własnym sumieniem i sposobem myślenia. Odwoływał się w ten sposób do koncepcji „Nauczyciela wewnętrznego", którą wyraził we wspomnianej już rozmowie z Adeodatem. Dowodził wówczas, iż uczniowie słuchając nauczyciela, sami we własnym wnętrzu rozważają prawdziwość głoszonej nauki. Nie byłoby to możliwe bez istnienia jakiegoś punktu odniesienia. Dokonuje się to zatem w ten sposób, jak twierdzi filozof, że „wpatrują się, jak potrafią, w ową wewnętrzną Prawdę. (...) O tym bowiem, czy prawdą jest to, co słyszymy, pouczyć nas może tylko Ten, który przez słowa $\mathrm{z}$ zewnątrz przypomniał nam, że mieszka w naszym wnętrzu" (Augustyn 1999a: XIV-45). Jednocześnie Augustyn starał się unikać w mowie poruszania trudnych zagadnień, zostawiając je raczej do opracowań pisemnych, co wynikało przede wszystkim z wielkiej potrzeby bycia zrozumianym. Jako wybitny retor, dopuszczał nawet stosowanie uproszczonych wyrażeń czy mowy potocznej, po to, aby słuchacze bardziej skupili się na sensie tego, co chciał przekazać, niż na formie jego przekazu. Przy wygłaszaniu kazań czy mów publicznych Augustyn zwracał także uwagę na twarze słuchających, na których pojawiały się oznaki zrozumienia. Jeśli ich nie widzial - tak długo omawiał daną kwestię, podawał coraz prostsze przykłady, aż jego 
słuchacze zrozumieli, i wówczas mógł przejść do kolejnego tematu lub zakończyć wypowiedź (Augustyn 1989: VII.21-X.25).

Kwestia zrozumienia tematu przez ucznia była dla Augustyna kluczowa, zatem stosował również metodę podsumowywania omawianego tematu na różnych etapach rozmowy. Zadanie to pozostawiał swojemu interlokutorowi, ponieważ sposób ten umożliwiał nie tylko wychwycenie błędów w jego rozumowaniu czy niedostatecznie wyjaśnionych kwestii, ale również dostrzeżenie przez nauczyciela nowych zagadnień lub postawienie ich w innym świetle niż dotychczas. W procesie tym role ucznia i nauczyciela mogą ulegać zamianie, skoro nauczycielem jest każdy, kto używa słów (Augustyn 1999a: VIII-21). Augustyn wskazywał w ten sposób na fakt, że uczniowie, stając się aktywni, zmieniają się z odbiorców wiedzy w osoby dzielące się swoim doświadczeniem i przemyśleniami - co z kolei może służyć pomocą nauczycielowi. Powinna to być zatem relacja oparta na wzajemnym szacunku (Francis 2016: 17). Znaczenie zrozumienia omawianego przez uczącego tematu podkreślał Augustyn, twierdząc, że jeśli nie dojdzie do tego ważkiego elementu, to można powiedzieć, że proces nauczania w ogóle nie miał miejsca: „Czymże jest nauczanie, jeśli nie podawaniem nauki? Oba tak się ze sobą łączą, że jednego bez drugiego nie może być. Nikogo się nie uczy, o ile on się nie nauczy, a nikt się nie nauczy, jeśli się go uczyć nie będzie. I dlatego, jeżeli uczeń nie jest zdolny do pojęcia tego, co mówi nauczyciel, to ten ostatni nie może powiedzieć: Ja go uczyłem, ale on się nie nauczył. Natomiast może powiedzieć: bo nie dotarło do niego, nie pojął, nie zrozumiał" (Augustyn 1986b: Ps 118[17], 3).

Augustyn zauważał również ważną rolę odwoływania się do wiedzy słuchającego oraz nauki poprzez doświadczenie. Człowiek nie rozumie, co oznacza słowo określające jakąś rzecz, jeśli wcześniej go nie poznał ani nigdy nie widział, jak wygląda coś, co określa ta nazwa. Uczniowi można objaśnić nowe wyrażenia, opisując je za pomocą tych słów, które już zna lub pokazując objaśniany przedmiot: „Wiedziałem to już poprzednio i zapoznałem się z tymi rzeczami nie dzięki temu, że inni je tak nazywali, lecz przez to, że sam je zobaczyłem" (Augustyn 1999a: X-33). Wiedzę zatem zdobywa człowiek nie poprzez samo stosowanie słów, ale dzięki poznaniu ich znaczenia: „Słowa mają tylko tę wartość - i to już najłaskawiej je oceniając - że pobudzają nas do szukania rzeczy, ale nie pokazują nam ich w ten 
sposób, żebyśmy mogli je poznać. Aby nauczyć mnie czegoś, trzeba, żeby przedmiot, który chcę poznać, ukazał się moim oczom lub podziałał bezpośrednio na którykolwiek mój zmysł lub też przedstawił się samemu umysłowi” (Augustyn 1999a: XI-36). Wyłania się tu prawdziwy cel nauczania według Augustyna - nie tyle jest to nauka nowych rzeczy za pomocą jedynie słów lub przypominanie sobie tego, co już człowiek wie, ale przede wszystkim pobudzenie ucznia do poszukiwania prawdziwej mądrości.

Pomimo porzucenia kariery retora, biskup z Hippony potrafił wciąż głosić swoje nauki w sposób elokwentny, łatwy do zapamiętania, a nawet prowokacyjny. W wielu jego mowach i pismach można znaleźć krótkie sentencje, które służyły zapamiętaniu najważniejszych życiowych kwestii, np. „Kochaj i czyń co chcesz; Zdobądź miłość, a posiądziesz wszystko; Kiedy milknie modlitwa? Kiedy stygnie pragnienie" (Martin 2003: 66-67).

W procesie dążenia do poznania prawdy ważna jest nie tylko motywacja wewnętrzna, ale również uznanie u nauczyciela. Augustyn stosuje w swoich dialogach pochwały wobec rozmówców, doceniając ich mądrość, bystrość i spostrzegawczość (Augustyn 1999a: VIII-22). Takie słowa motywują ucznia o tyle, o ile sam nauczyciel posiada w jego oczach autorytet. Adeodat w dialogu ze swoim ojcem zdaje się całkowicie na jego prowadzenie, mówiąc: „Postępuj raczej dalej tak, jak zacząłeś. Nigdy bowiem nie mógłbym przypuszczać, że zasługuje na lekceważenie to, co ty uznałeś za godne omówienia lub wykonania” (Augustyn 1999a: VIII-21). Takie zaufanie mądrości i prowadzeniu przez nauczyciela jest istotne, szczególnie wówczas, gdy przeżywamy upadek twierdzeń uważanych przez nas za pewne i trwałe (Augustyn 1999a: X-31).

W nauczaniu niezwykle istotna jest również osobowość samego nauczyciela, która wywiera ogromny wpływ na sposób głoszenia i przyjmowania treści. Dla biskupa z Hippony bardzo ważna była kwestia życia zgodnie ze słowami, które wygłaszał, ale również podnoszenie swych umiejętności z zakresu retoryki w celu wykładania prawdziwej nauki. Sam Augustyn z jednej strony nieustannie odczuwał dysonans między „błyskiem zrozumienia”, jaki posiadał we własnym wnętrzu, a wypowiadanymi słowami, a z drugiej - potrafił swą wymową zachwycić słuchających. Nie dorównywał stylem Grzegorzowi z Nazjanzu ani kwiecistej wyobraźni Jana Chryzostoma, ale 
posiadał inny ogromny atut - głębię myśli i pewność słowa przy jednoczesnej bezpośredniości i ciepłej uczuciowości. Augustyn - nawiązując do Cycerona - rozróżniał trzy rodzaje wymowy: prostą, kwiecistą i patetyczną. Sam potrafił płynnie używać każdej z nich i przechodzić pomiędzy jednym stylem a drugim (Trapè 1987: 144-145).

Zaprezentowane fragmenty nauczania św. Augustyna wskazują na najważniejsze elementy, jakimi powinien się cechować dobry pedagog. Priorytetową kwestią jest pobudzenie ucznia do poszukiwania prawdziwej mądrości. Można to osiągnąć przede wszystkim poprzez zrozumienie przez niego wykładanych treści. Proces ten wspomagany jest stosowaniem przez nauczyciela prostych porównań, krótkich sekwencji ułatwiających zapamiętanie tematu czy przypominanie sobie już znanych uczniowi kwestii. Istotna jest również osobowość samego nauczyciela, który powinien inspirować do osiągania tegoż celu poprzez prowadzenie życia zgodnego $z$ własnym nauczaniem, a także bycie otwartym na zdobywanie nowej wiedzy.

\section{Wskazówki dla nauczycieli}

Augustyn miał wpływ na wiele osób, które następnie nauczały innych. Ze wspólnoty, którą założył, pochodziło choćby kilku późniejszych biskupów i kapłanów (Possydiusz z Kalamy 2002: XI, 1-6). Był podziwianym retorem, dlatego zwracano się do niego również $\mathrm{z}$ pytaniem o sposób wykładania religii i innych nauk. W takim kontekście powstało dzieło Poczatkowe nauczanie religii (Augustyn 1952), które jest niezwykle bogate we wskazania udzielane nauczycielom.

Pierwszą kwestią, na którą Augustyn zwraca uwagę, jest pokora przemawiającego wiążąca się z zaakceptowaniem przez niego ograniczoności słów, za pomocą których naucza. Filozof podkreśla, że nauczyciel chciałby, aby uczeń zrozumiał wykładane treści tak, jak rozumie je sam uczący, nie jest to jednak zawsze możliwe ze względu na narzędzie, którym się posługuje - język. Problem dotyczy bowiem sposobu, w jaki zachodzi w umyśle rozumiejącego poznanie: „Owo zrozumienie jakby nagłą błyskawicą przenika umysł, podczas gdy mowa jest powolna, długa i bardzo niepodobna, i gdy się ona rozwija, już tamto zrozumienie w tajemnych głębinach się skryło" (Augustyn 1952: II, 3). Nauczyciel próbuje przenieść doświadczenie, które nie istnieje w formie słów, na wymawiane przez siebie pojęcia. 
Nie jest to do końca możliwe, jednak ta niemożność nie powinna, według Augustyna, stanowić bariery w nauczaniu. Trzeba się pogodzić $\mathrm{z}$ istniejącym ograniczeniem, ufając, że każdy zrozumie daną kwestię na miarę swoich możliwości i w sobie właściwy sposób oraz nie pozwalając, aby spowodowało ono nadmierny smutek czy zmartwienie u nauczyciela. Augustyn dowodzi bowiem, że uczniowie dużo chętniej słuchają tych, którzy znajdują upodobanie w nauczaniu (Augustyn 1952: II, 4). Filozof nie zwalnia jednak nauczyciela z obowiązku przedstawiania treści w taki sposób, aby uczeń je zrozumiał, nawet jeśli słowa redukują owo zrozumienie przez swą ograniczoność. Samo wygłoszenie nauki, według Augustyna, nie jest jeszcze bowiem nauczaniem: „Choć bowiem wygłosił to, co sam rozumie, nie powinien sądzić, że spełnił swój obowiązek wobec słuchacza, który go nie zrozumiał” (Augustyn 1989: XII.27). Natomiast gdy już proces ten nastąpił, a więc uczeń zrozumiał wykładane treści, ważne jest, aby go zachwycić i wzruszyć w celu utrwalenia efektu nauczania poprzez utrzymanie uwagi ucznia oraz pobudzenie go do działania. $Z$ tego względu Augustyn podkreśla, jak ważny jest sposób prowadzenia wykładu, który wymaga od nauczyciela nabycia elokwencji i znajomości podstaw sztuki oratorskiej. Przypomina jednocześnie o właściwej kolejności procesu nauczania - najważniejsze jest zrozumienie, a pozostałe elementy mają znaczenie dopiero po osiągnięciu tego pierwszego etapu (Augustyn 1989: XII.26-27).

Drugim charakterystycznym elementem procesu nauczania, o którym pisze Augustyn, jest postawienie w jego centrum samego ucznia, którego słowa pedagoga mają budować i kierować ku zdobywaniu mądrości, a nie tylko wiedzy: „Cokolwiek wykładasz, wykładaj tak, aby uczeń słuchając - wierzył, wierząc - miał nadzieję, a mając nadzieję - miłował" (Augustyn 1952: IV, 8). Augustyna bowiem interesuje człowiek jako całość, a nie tylko jego poziom wiedzy czy wykształcenia. Stwierdza, że proces edukacji ma wzmocnić człowieka moralnie, aby potrafil na co dzień się przeciwstawić otaczającemu go złu i nie dał się zwieść oszustom czy nie był podatny na zgorszenia, a także duchowo - aby w każdej sytuacji nadzieję pokładał w Bogu, a nie w człowieku, który może go zawieść (Augustyn 1952: VII, 11): „Kiedy natomiast dusza pogłębia mądrość, którą znalazła; kiedy do niej jest cała zwrócona; kiedy nie dbając o marności tego świata, nie zwraca się do bożyszczy zwodniczych, które - jeśli tylko 
dusza znajdzie w nich upodobanie - zazwyczaj odrywają ją swoim ciężarem od Boga i w przepaść strącają - wówczas to nie potrzebuje się obawiać żadnego przekroczenia miary, a zatem żadnego niedostatku i żadnego nieszczęścia. Właściwą sobie miarę, to jest mądrość, posiada więc każdy człowiek szczęśliwy" (Augustyn 1999b: IV-36).

Analizując proces edukacji, Augustyn podejmuje także zagadnienie nauczania poprzez doświadczenie: „Chodzi o to, aby nie pokazywać tego niby w zwojach i zaraz z widoku zabierać, ale zatrzymując się przez pewien czas rozwiązać to niejako i rozłożyć, i przedstawić umysłom słuchaczy, na co należy patrzeć i podziwiać, resztę zaś szybko przechodząc spleść z całością” (Augustyn 1952: III, 5). Jak wcześniej zostało wspomniane, człowiek uczy się nowych pojęć jedynie przez doświadczenie lub wyjaśnienie za pomocą znanych już słów. Augustyn jednak, pragnąc wzmocnić efekt przyswojenia nowych treści, zwraca uwagę ucznia na rzeczy najważniejsze, aby całość wykładu pozostała spójna. Wybiera dla niego to, co jest najbardziej godne podziwu i przyjemne do słuchania. Pozwala się mu zatrzymać, aby mógł się zachwycić zdobytą wiedzą, jednocześnie nie tracąc z oczu tych istotnych treści. Biskup z Hippony był bowiem również miłośnikiem piękna i harmonii świata, w którym odkrywał działanie samego Boga. Uprzywilejowanym zaś ośrodkiem piękna, według niego, jest człowiek oraz jego historia namalowana ręką Boskiego Artysty. I do odkrycia tej właśnie prawdy retor pragnie doprowadzić każdego swego ucznia (Trapè 1987: 250-252).

Według Augustyna indywidualne podejście do każdego ucznia jest następnym ważnym aspektem edukacji innych. Na początku należy zatem rozpoznać prawdziwy cel przyjścia danego człowieka do nauczyciela - najlepiej pytając go o to wprost. W przypadku gdy uczeń nie jest szczery, Augustyn radzi, aby nie udowadniać mu kłamstwa, lecz uwierzyć i rozpoczać naukę zgodnie z treścią odpowiedzi, a wykład poprowadzić w taki sposób, aby pomóc uczniowi wskazać prawdziwą motywację. W zależności od tego, kim jest osoba objęta edukacją, należy zróżnicować także treść wykładu. W przypadku kogoś, kto nie ma żadnej wiedzy ani wykształcenia, należy wprowadzać wszystkie treści powoli, dokładnie je omawiając. W sytuacji, gdy na naukę przychodzi osoba wykształcona w zwykłej szkole, trzeba wykład przeprowadzić dokładnie, jednak nacisk położyć na rugowanie pychy. W czasach kończącej się epoki starożytności pycha, wynikająca 
z nabycia podstawowej wiedzy, była dość powszechnym problemem. Jeśli mamy do czynienia z osobą wykształconą „w naukach wyzwolonych", wystarczy jedynie pokrótce wytłumaczyć najważniejsze kwestie, jednocześnie wskazując np. błędy w czytanych przez ucznia książkach (Augustyn 1952: V,9-IX,13). Ze względu na fakt, że Augustyn sam należał do ostatniej grupy, na szczególną uwagę zasługuje jego sposób pobudzania do samodzielnego myślenia osób już wykształconych, które potraktowane zbyt pobłażliwie, nieadekwatnie do ich poziomu intelektualnego, mogłyby się zniechęcić do nauki: „Z tymi zatem pokrótce należy się załatwić, aby ich nie zniechęcać powtarzaniem tego, co znają, lecz pokrótce to przechodzić, wyrażając wiarę w ich zaznajomienie się już z tym i owym. Przebiegniesz więc wszystko, co nieumiejętnym i nieuczonym wpoić trzeba w taki sposób, aby ten umiejętny, znając to, słuchał nie jak od nauczyciela, a jeśli jeszcze czego nie wie (chociaż dawaliśmy wiarę, że już wie), by tego się nauczył, gdy o tym napomykamy" (Augustyn 1952: VIII, 12).

Według Augustyna, jak zostało to zasygnalizowane wcześniej, w nauczaniu bardzo ważna jest osobowość nauczyciela. Powinien on być nie tylko wykształcony, nauczać prawdy, pobudzać do dążenia do poznania mądrości, żyć w zgodzie z tym, co głosi, ale również być radosny. Nie może się zatem poddawać łatwo codziennemu zniechęceniu i trudom, ale powinien przezwyciężać je dzięki wierze. Nauczyciel, który żyje w obecności Boga i ma czyste sumienie, będzie wobec słuchających go promieniował prawdziwą radością. Z kolei uczniom można tę cechę osobowości okazywać nie tylko podczas wykładu, ale przede wszystkim poprzez często prowadzone rozmowy (Firosz 1999: 128-133).

W Poczq̨tkowym nauczaniu religii Augustyn poświęcił również wiele miejsca trudnościom, z jakimi może spotykać się w swojej pracy nauczyciel oraz sposobom ich pokonywania. Pierwsza z przeszkód, opisana już wcześniej, to nieudolność i słabość mowy, co powoduje pewne napięcie wewnętrzne nauczającego. W Objaśnieniach Psalmórw kaznodzieja ujmuje to w następujących słowach: „Szczęśliwsi są ci, którzy słuchają, niż ci, którzy mówią. Ten, kto się uczy, jest pokorny. Ten, kto uczy, musi się trudzić, aby nie był pysznym, żeby nie wcisnęło się uczucie złego upodobania, aby nie obrzydł Bogu ten, kto pragnie się ludziom podobać. Nauczający odczuwa wielki lęk, bracia moi, wielkie drżenie odczuwa się w tych naszych słowach. Uwierzcie 
naszemu sercu w to, czego nie możecie zobaczyć” (Augustyn 1986a: Ps 50[13]). Kolejna trudność pojawia się w przypadku nauczania podstawowych zagadnień, które często są dla samego nauczyciela zbyt łatwe i nużące, a w konsekwencji mogą osłabiać jego entuzjazm. Innym utrudnieniem dla nauczyciela jest „słuchacz martwy, bo albo go nie wzrusza uczucie, albo żadnym ruchem ciała nie okazuje, że rozumie i że mu się podoba, co mówimy” (Augustyn 1952: X, 14). Zdarza się również, że nauczyciel przychodzi na zajęcia oderwany od czynności, które bardzo lubi, a prowadzenie nauki jest dla niego wówczas mniej przyjemne, wtedy odczuwane przez pedagoga zasmucenie ma również negatywny wpływ na ucznia. Podobnie dzieje się w przypadku osobistych wydarzeń z życia nauczającego, powodujących u niego wielki żal i smutek. Środków zaradczych na te trudne sytuacje Augustyn zaleca szukać w wierze i modlitwie. Podpowiada, by w duchu spoglądać na Jezusa Chrystusa i Jego przykład życia oraz kierować się miłością braterską (Augustyn 1952: X.15-XIV.22).

Innym zagrożeniem dla nauczyciela mogą się stać ludzkie pochwały lub nagany. Sam Augustyn wyznaje w objaśnieniu Psalmu 66, że jako pasterza odpowiedzialnego za powierzony mu lud cieszą go właśnie nie tyle ludzkie pochwały, co raczej postęp duchowy wiernych, czyli pobożność i czyny wypływające z wiary, co stanowi wskazówkę dla pedagogów, jakie wartości powinny być najważniejsze $\mathrm{w}$ procesie nauczania innych. $\mathrm{Na}$ niebezpieczeństwo narażeni są szczególnie nauczyciele pragnący ludzkich zaszczytów. Lekarstwem na te trudności jest według biskupa $\mathrm{z}$ Hippony modlitwa oraz odpowiednia formacja tych, którzy mają głosić naukę innym (Strankowski 2013: 310-312).

Augustyn udziela również praktycznych rad nauczycielom, którzy popełnili błąd w trakcie prowadzenia swojego wykładu. Najlepiej wówczas spokojnie poprawić swoją wypowiedź, żeby - próbując jej bronić - nie popaść w jeszcze większy błąd. Jeśli jednak pedagog nie zauważy swego błędu, a nie zwrócą na niego również uwagi słuchacze, można go zignorować, przy jednoczesnym staraniu, aby nie popełnić kolejnych pomyłek. Zdarzają się także sytuacje, w których uczniowie czerpią radość z takiego wydarzenia, często jeszcze obmawiając osobę wykładającą. Filozof radzi, aby w takim przypadku wyłożyć ponownie prawidłową wersję, która powinna skłonić słuchacza do refleksji i poprawy swojej postawy (Augustyn 1952: XI, 16). 
W kontekście tych trudności Augustyn podkreśla również konieczność zastosowania różnego rodzaju wykładu i sposobu nauczania w zależności od towarzyszących mu okoliczności i od osób słuchających nauki. Wskazuje także w ten sposób na niemożność podania jednego, uniwersalnego sposobu dzielenia się wiedzą: „Kiedy zajmujemy się teraz sprawą zaspokojenia duchowego głodu nieumiejętnych, ja sam jestem Ci świadkiem, że za każdym razem inaczej przystosowuję usposobienie mego serca, gdy widzę przed sobą - wykształconego albo niepiśmiennego, obywatela obcego, bogatego, ubogiego, nie mającego urzędu, piastującego godności, władzę jakąś dzierżawiącego, człowieka $\mathrm{z}$ tego lub owego narodu, tej lub owej kategorii wieku lub płci, przychodzącego z tej lub owej sekty, z tego lub owego pospolitego błędu i odpowiednio do należnego usposobienia serca mowa moja stawia kroki, postępuje i kończy się"(Augustyn 1952: XV, 23).

\section{Zakończenie}

Augustyn nigdy nie marnował okazji do tego, by nauczać potrzebujących - w publicznych dysputach, w rozmowach przy stole, w kazaniach, ale również w listach dydaktycznych. Jego doświadczenie przedmiotowego traktowania ucznia, które wyniósł z dzieciństwa, a następnie przekazywanie fałszywych treści, z jakim spotkał się w młodości, zaowocowały stworzeniem przez niego własnej koncepcji edukacji. Charakterystyczne jest dla niej położenie ogromnego nacisku na zrozumienie wykładanych treści przez ucznia, dopasowanie ich do poziomu inteligencji słuchającego, ale także do jego potrzeb. Nauczyciel powinien być nie tylko dobrym oratorem, ale przede wszystkim - nawet kosztem błędów językowych - tym, który prowadzi do poznania i ciągłego poszukiwania prawdziwej mądrości. Nie wystarczą tu jednak same słowa - musi on również żyć tym, co głosi. W przeciwnym razie jego przekaz będzie mało wiarygodny, a dzieci i młodzież są na to szczególnie wyczuleni, o czym świadczą wspomnienia samego Augustyna z czasów dzieciństwa i młodości. Zrozumiałe jest dla niego zniechęcenie czy doświadczanie trudności przez nauczyciela, jednak nie powinno to skłaniać pedagoga do rezygnacji, ale raczej do wzmocnienia fundamentu wiary i refleksji nad sposobem prowadzenia zajęć lub rewizji własnego postępowania. Dla Augustyna ważna jest również motywacja ucznia, którą należy 
odkryć i pomóc oczyścić, m.in. poprzez redukcję rzeczy rozpraszających go w dążeniu do zdobywania mądrości. Najważniejszym pojęciem odkrytym przez Augustyna jest „Nauczyciel wewnętrzny”, którym jest sam Bóg mieszkający w sercu człowieka. To On pozwala ocenić uczniowi, czy przedstawiane mu treści są zgodne z prawdą oraz czy należy je przyjąć.

$\mathrm{Na}$ podstawie przeprowadzonej w niniejszym artykule analizy podejścia św. Augustyna do zagadnienia nauczania można wyróżnić trzy podstawowe filary tego procesu:

1. Prawda - nauczyciel powinien nauczać rzeczy, które są prawdą o Bogu i człowieku, a nie zwodzić ucznia na manowce za pomocą rozbudowanej elokwencji. Podstawą jest tutaj zatem zdobywanie rzeczywistej Mądrości. Ważnym aspektem jest również konieczność stawania w prawdzie o swojej własnej kondycji jako nauczyciela, życie w zgodzie z tym, co się głosi, ale jednocześnie pomoc uczniowi w odkryciu prawdziwej motywacji, która skłania go do zdobywania Mądrości. Każdy człowiek posiada także „Nauczyciela wewnętrznego”, który pomaga mu weryfikować prawdziwość przedstawianych zagadnień. Jeśli pedagog głosi twierdzenia sprzeczne $\mathrm{z}$ nauką Bożą lub żyje w zupełnej sprzeczności z tym, co wykłada, istnieje duże prawdopodobieństwo, że uczeń po prostu odrzuci jego naukę z powodu dysonansu, jakiego doświadcza.

2. Zrozumienie - jeśli uczeń nie zrozumiał wykładu, proces nauczania w ogóle nie nastąił. Augustyn dopuszcza uproszczenie mowy przez nauczyciela, a nawet używanie potocznych słów tylko po to, by słuchacz pojął przedstawiane mu treści. Sam również używa wielu przykładów, krótkich myśli, aby umożliwić zapamiętanie najważniejszych elementów wykładu. Indywidualizacja podejścia do ucznia wprowadzana jest po to, aby dopasować do niego zarówno sposób prezentacji, jak i zasób przedstawianych treści. Cel jest zawsze jeden: uczeń powinien móc zrozumieć to, co mówi do niego nauczyciel, pomimo pewnych ograniczeń, choćby wynikających z konieczności użycia słów.

3. Miłość - do skutecznego prowadzenia wykładu niezbędna jest miłość do Boga i drugiego człowieka. Wówczas nauczyciel może z wyrozumiałością podejść do ucznia, który potrzebuje 
od niego więcej cierpliwości. To właśnie miłość stanowi najważniejszą motywację do nauczania oraz pokonywania wielu przeszkód występujących w procesie edukacji. Często wymaga to zapomnienia o sobie samym i koncentracji na Jezusie, który jest miłością i który żyje w drugim człowieku.

\section{Bibliografia}

Augustyn św. (1952). Poczatkowe nauczanie religii, [w:] tegoż, Pisma katechetyczne, Warszawa: Instytut Wydawniczy Pax.

Augustyn św. (1986a). Objaśnienia Psalmów. Ps 36-57, przeł. J. Sulowski (Pisma Starochrześcijańskich Pisarzy, t. 38), Warszawa: Akademia Teologii Katolickiej.

Augustyn św. (1986b). Objaśnienia Psalmów. Ps 103-123, przeł. J. Sulowski (Pisma Starochrześcijańskich Pisarzy, t. 41), Warszawa: Akademia Teologii Katolickiej.

Augustyn św. (1989). O nauce chrześcijańskiej, przeł. J. Sulowski, Warszawa: Instytut Wydawniczy Pax.

Augustyn św. (1999a). O Nauczycielu, [w:] tegoż, Dialogi filozoficzne, red. K. Tarnowski, przeł. J. Modrzejewski, Kraków: Znak, s. 433-485.

Augustyn św. (1999b). O życiu szczésliwym, [w:] tegoż, Dialogi filozoficzne, red. K. Tarnowski, przeł. A. Świderkówna, Kraków: Znak, s. 15-50.

Augustyn św. (1999c). Solilokwia, [w:] tegoż, Dialogi filozoficzne, red. K. Tarnowski, przeł. A. Świderkówna, Kraków: Znak, s. 239-305.

Augustyn św. (2007). Wyznania, przeł. Z. Kubiak, Kraków: Znak.

Firosz A.K. (1999). Koncepcja katechezy w pismach śrw. Augustyna, Lublin: Redakcja Wydawnictw KUL.

Francis E. (2016). Augustinian Educational Theory, Las Vegas (NV): Xlibris. Martin T.F. (2003). Our Restless Heart: The Augustinian Tradition, New York: Orbis Books.

Possydiusz z Kalamy (2002). Żyzot św. Augustyna, przeł. P. Nehring, Kraków: Tyniec Wydawnictwo Benedyktynów.

Strankowski M.(2013). Zagrożenia w przepowiadaniu Stowa Bożego w świetle „Enarrationes in psalmos” św. Augustyna,„Vox Patrum” t. 60, s. 289-314.

Trapè A. (1987). Święty Augustyn. Cztowiek - duszpasterz - mistyk, przel. J. Sulowski, Warszawa: Instytut Wydawniczy Pax.

\section{ADRES DO KORESPONDENCJI}

Mgr inż. Dorota Anna Kowalewska OSA

e-mail: s.dorota.osa@gmail.com 